\title{
極めて重篤な経過をとった
}

$$
\text { ルードウィッヒ・アンギーナ }
$$

大越 俊和 ${ }^{1)}$ 中中島 博昭 ${ }^{1)} \cdot$ 大竹 英夫 ${ }^{1)}$

竹山 勇 ${ }^{1)}$ 長田 博昭 ${ }^{2)} \cdot$ 佐藤 忠一 ${ }^{3)}$

\section{A Case of Ludwig's Angina with Many}

\section{Serious Complications}

\section{Toshikazu Okoshi, Hiroaki Nakashima, Hideo Ohtake, Isamu Takeyama, Hiroaki Osada and Chuichi Sato}

(St. Marianna University School of Mecicine)

A 51-year-old diabetic male patient who developed lifethreatening Ludwig's angina from a dental infection is presented. In spite of initial treatment consisting of antibiotics and surgical decompression, the infection extended to the abdominal cavity. Therefore, trachostomy and drainage of bilateral thorax, mediastimum and pericardium were performed. The decreased defense system of the diabetic patient was considered to have prolonged the infection.

Key words: Ludwig's angina, diabetes mellitus, tracheostomy, thoracotomy

緒 $\quad$ 言
ルードウィッヒ・アンギーナは, Wilhelm

Friedlich von Ludwig によって1836年に報告 された口腔底の蜂窩織炎であり, 炎症が限局せ ずにあらゆる間隙を伝って，急速に，び慢性に 進行し, 短時間のらちに喉頭水腫, 縱隔炎, 肺 炎, 敗血症等を起して化学療法の発達前は多く を死に至らしめた重篤な疾患である.

今回私共は, 萭歯より生じた炎症が頸部及び 胸腔のみならず，腹腔にまで達した極めて重篤 な症例を経験し，治㾑せしめたのでここにその 概要を報告する。

\author{
症 \\ 例 \\ 患者: 51 才, 男性. \\ 初診：炤和59年 2 月 2 日. \\ 主訴 : 頸部腫脹, 呼吸困難. \\ 家族歴：特記すべきことなし。 \\ 既往歴 : 昭和58年会社の健康診断にて糖尿病 \\ の疑いを指摘. \\ 現病歴: 昭和59年 1 月28日午前, 煎餅を食し \\ た時右歯痛があった。 同日午後右下澦米の自発 \\ 痛が出現したが，市肘の鎮痛剂を服用して様子 \\ をみていた。1月30日歯痛増強し, 顎下部腫脹 \\ が出現してきたため, 某病院㮀科受診し, 米性
}
1）聖マリアンナ医科大学耳息咽喉科学教室
2) 聖マリアンナ医科大学第 3 外科学教室
3）聖マリアンナ医科大学第 2 内科学教室 
顎骨炎と診断され即時入院となった. 入院後牘 下部を数回穿刺されたが膿は認められなかっ た. 1 月31日腫脹がさらに拡がり, 䫏下部, 左 下顎部の切開を受けたが排膿はみられなかっ た. 2 月 1 日左下頸部より排膿あり，ドレナー ジ施行されたが，発熱及び呼吸苦を訴光たため 某歯科大学口腔外科に転院となった．転院後右 臼歯後部を切開され排膿を認め，また頃下部よ り膿の流出もみられた。 2 月 2 日右下顎部, 監 部より前胸部にかけて発赤, 腫脹が増強し, 燕 下困難，開口障害持続し，呼吸困難増強したた め, 同日夕方当科紹介され転院となった。

入院時所見：意識は清明であったが，極めて 強い頸部腫脹があり，両䫈下部より前胸部にか けて緊張した発赤を伴ら硬結がみられた。開口 障害が認められ，約 1 横指しか開かず，悪臭が あり，呼吸苦が認められた。 ドレーンが左下顎 角及び願下部に挿入され，排膿が少量認められ た.

入院時検査成績 : 血液一般検査においては白 血球数 9700 , 赤血球数 351 万, $\mathrm{Hb} 10.7 \mathrm{~g} / \mathrm{dl}$, Ht 33.5\%, T. Bil $1.1 \mathrm{mg} / \mathrm{dl}$, GOT $20 \mathrm{mU} / \mathrm{dl}$, GPT $17 \mathrm{mU} / \mathrm{dl}$, LDH $350 \mathrm{mU} / \mathrm{dl}$, アミラーゼ $194 \mathrm{SU}$, TP $6.3 \mathrm{~g} / \mathrm{dl}$, BUN $34 \mathrm{mg} / \mathrm{dl}$, クレアチ ニン $0.9 \mathrm{mg} / \mathrm{dl}, \mathrm{Na} 138 \mathrm{mEg} / \mathrm{l}, \mathrm{K} 3.3 \mathrm{mEq} / \mathrm{l}$, $\mathrm{Cl} 101 \mathrm{mEq} / 1$, 尿検査にて蛋白 $(+)$, 糖 $(+)$, ケト ン(H), 動脈血液ガス所見 $\mathrm{pH} 7.487, \mathrm{Pco}_{2} 34.3$ $\mathrm{mmHg}, \mathrm{PO}_{2} 80.3 \mathrm{mmHg}, \mathrm{HCO}_{3} 25.3 \mathrm{mEq} / \mathrm{l}$, BE 2.7, SAT 95.6\%, 胸部単純 X-P にて気腫 を伴った強度の頸部腫脹が認められた（図 1).

処置及び経過（図 2 ）：入院時所見及び 検査 結果より今後, 呼吸困難が増加し, 窒息の危険 もあるため, 緊急気管切開術を施行し, 頸部ド レナージを追加した，手術時所見，口腔内に異 臭があり, 舌は挙上し, 右大臼歯の内側後方に 他院でドレナージされた瘦孔があり，左下顎角 のドレーンと交通していた。 気管切開に際し, 気切創下部より膿が漏出し, 緃隔洞炎に進行し ていると思われた。ドレーンを気切口，左下顎 角部に追加して手術を終了し, 術後血液ガス所

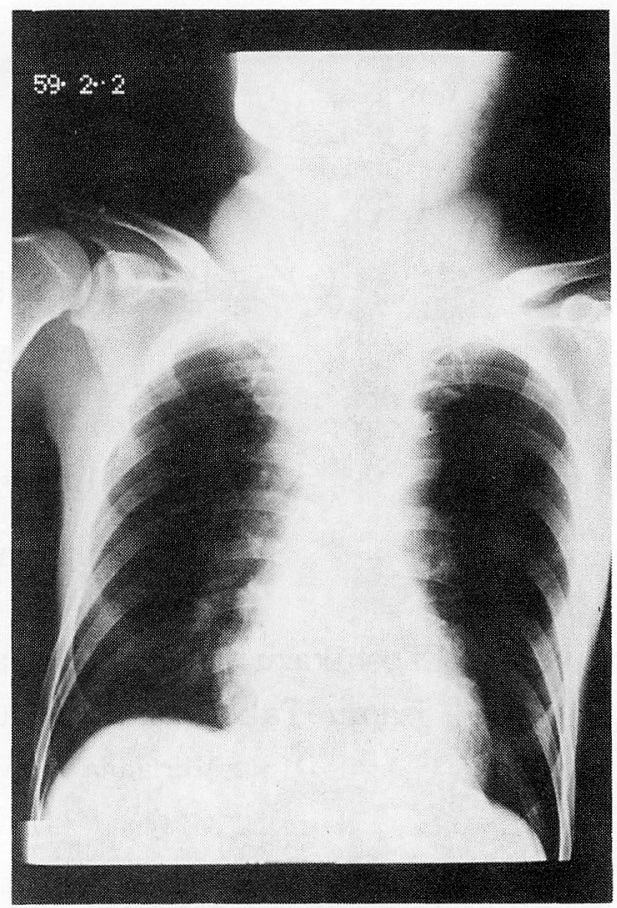

図 I 来院時の胸部 XP

気腫を伴った強度の頸部腫脹がみられる。

見の改善が認められた。 また抗生剤投与, 補液 を開始した。 2 月 3 日呼吸頻回となり,さらに 進行し, 胸部単純 X-P にて両側肺炎, 縦隔の 拡大, 心陰影の拡大（図３）を認めたため, 胸 部 CT 及び超音波エュー診断を行い， CT にて 両側胸膜腔，心囊，縦隔に膿瘍形成，左下葉の 閉塞所見がみられた (図 4).心エコーでは心軍 動は正常であったが心鼠液の貯留を認めた。 2 月 4 日炎症が胸腔すべてに波及していることが 判明したため, 胸部外科に依頼し緊急開胸術が 施行された，気管切開口より，気管分岐部前 面，大動脈後面，右胸鎖関節後面にそれぞれぺ ンローズドレーンを留置し，次いで胸骨剣状突 起下に切開を加えて心囊に達し膿を排出後, ア 一ガイルチェストチューブを挿入した．左胸腔 からは心䨴液同様の大量の膿が流出した。術後 人工呼吸器を装着して呼吸管理を行った。また IVH カテーテルを左上腕静脈より挿入し, 中 心静脈栄養を開始した。 2 月 6 日人工呼吸器よ 


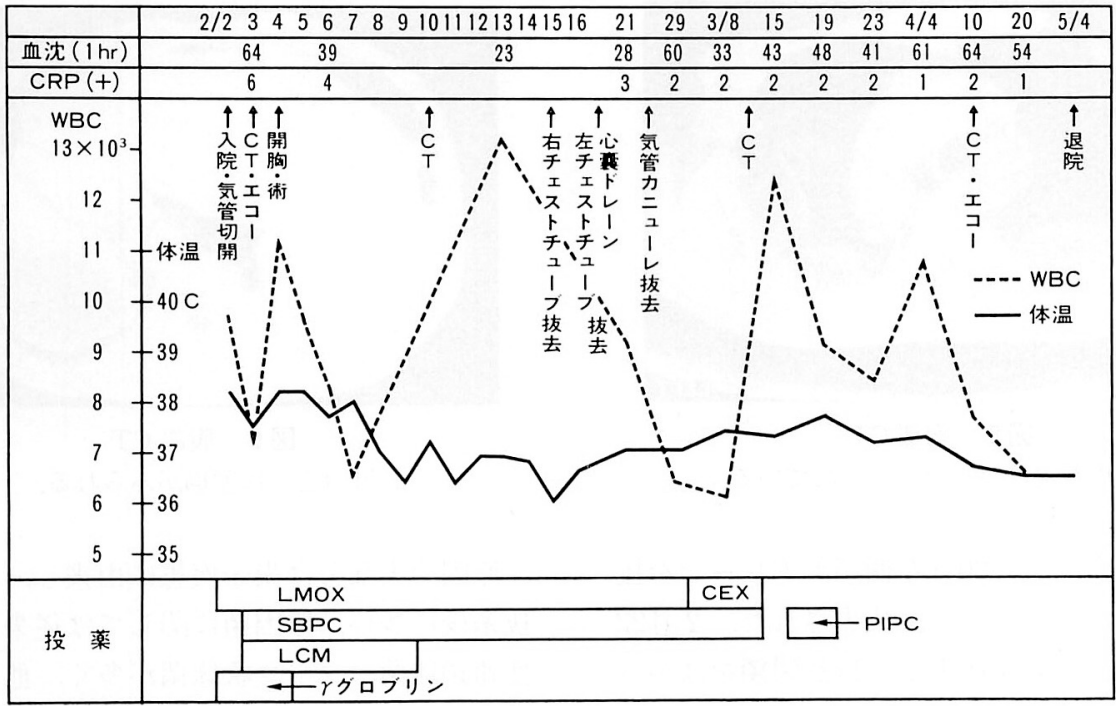

図 2 臨床経過及び処置

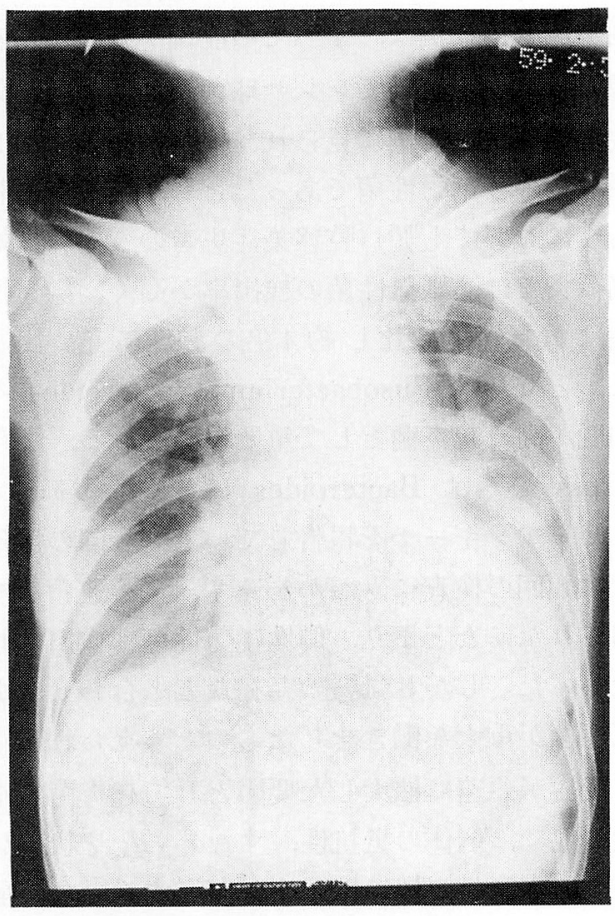

図 3 入院翌日の胸部 XP 両側肺炎及び縦隔，心㓌影の拡大がみられる。

り離脱，2月 7 日飲水開始，2月9日より食事 摂取開始し，中心静脈栄養を中止した。この

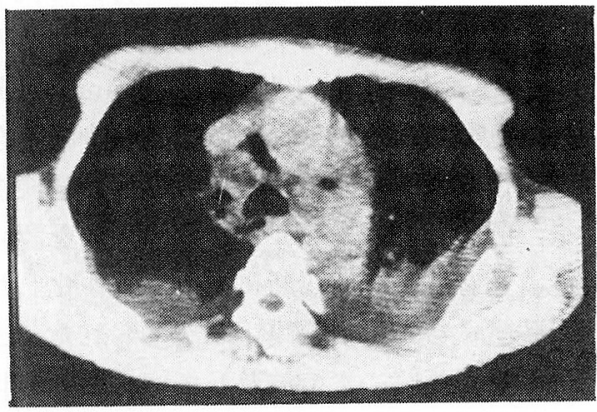

図 4 腹部 CT

気管周囲の気胞を伴った液体と胸膜腔膿瘍が みられる。

間，糖疗病を考虑しレギュラーインスリンを投 与していたが，2月10日より NPH インスリ ンに変えて血糖值のコントロールをはかった。

2 月14日胸部単純 X-P にて心陰影増強したた め，超音波エコー診断を行い，約 $200 \mathrm{ml}$ の心 垔液貯留を認めたが心機能上影響なしと判断さ れた。 2 月15日右チェストチューブ，気管傍ド レーンを抜去，2月16日胸部 CT にて両側の 胸水貯留がカプセル化されているのが認められ た（図 5 )。また心垔液の販留，縦隔膿瘍も認め られた。 2 月 18 日左チェストチューブ, 心装 


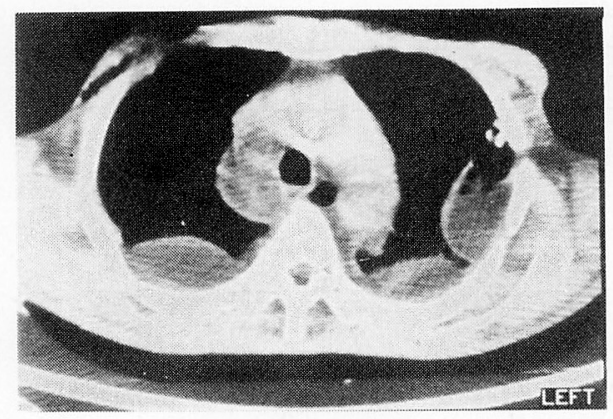

図 5 胸部 $\mathrm{CT}$

胸腔の膿瘍はカプセル化されている。

ドレーン抜去，2月20日左側頸部ドレーンを抜 去し，すべてのドレーンが抜去された， 2 月 22 日気管カニューレを抜去して自然閉鎖をはかっ た。 2 月29日同体位に打ける長期臥床による と考えられる左腓骨神経麻痺が出現していたた め，リハビリテーションを開始，3月10日抗生 郕投与を中止し，経過を見ることにした。その 後発熱 $37^{\circ} \mathrm{C}$ 台, 血沈 1 時間值 $40 \mathrm{~mm}, \mathrm{CPR}$ （H）の状態が持続するため再度の全身検索を 行らことにした. 4 月10日に施行した CT 検查 の結果，肝臓と同一レベルに，膿瘍形成を認め （図 6)，超音波エコー診断にてカプセル化した 膿瘍が脾臓に接して横隔膜下に認められた。こ の結果炎症が腹腔にまで波及していることが判 明したが，膿瘍はカプセル化されているのでこ れ以上進展しないとし，経過観察とした，発熱 はその後みられなくなり，炎症所見もしだいに 減少していったが，患者の糖尿病に対する病識 がうすく，血糖值が安定せず困難であったが患 者教育を十分に行い, 最終的にインスリン投与 值を確定して 5 月 4 日退院し, その後, 現在ま で異常を認めていない.

\section{考察}

口腔底内部は，互いに交通する柾性結合織の 内隙で占められ, 舌下隙, 顎下三角膜, 䫀下三 角隙が臨床上重要で，下方では縦隔洞と連絡し ているため, 口腔底の炎症は本症例の様に急速 に胸腔に進展波及し，重篤な状態をきたすこと がある。

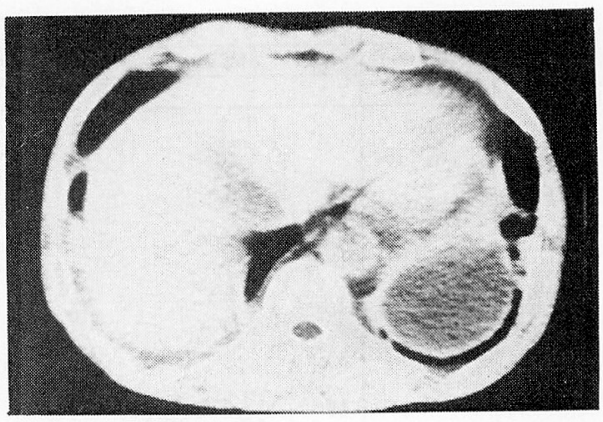

図 6 腹部 CT

肝臓と伴に膿痬がみられる。

原因の大部分は歯牙疾患に由来し，なかでも 抜系後に多い，原因菌に関しては従来上り溶血 性連鎖球菌, ブドウ状球菌が多く, 他に肺炎球 菌, 大腸菌, 嫌気性菌等の混合感染と言われて いる。森らの報告 ${ }^{1)}$ によると口腔内感染症患者 のうち, 顎骨炎, 歯槽骨炎, 蜂窩織炎による非 開放性膿瘍 12 例は，すべての症例が口腔内常在 菌による混合感染でレンサ球菌が最も多く, 偏 性嫌気性菌が 7 例に見られ, 検出菌の多くが 2 種以上の多剂耐性菌であったとし，渡辺らの報 告 ${ }^{2)}$ に批いても顎口腔感染症患者のらち特に蜂 窩織炎では，嫌気性菌の検出率が高く，嫌気性 菌は好気性菌に比し約 4 倍の頻度に見い出さ れ，とりわけ Fusobacterium, Bacteroides の 頻度が高く起炎菌として重要視している。また Gross ら² は Bacteroides によるルードウィ ッヒ・アンギーナを報告している，今回の症例 では頻回の検査にもかかわらず， $\beta$ 溶連菌が検 出されたにとどまり，偏性嫌気性菌は検出され なかった。しかし気腫の存在などと合わせ，嫌 気性菌が重大な働きをしたものと考党られる。

炎症が急速に払大した要因として起炎菌の毒 性の他に，個体の抵抗性，すなわち全身状態が 㐫る。本症例の様に糖尿病が存在する場合, 宿 主の感受性，すなわら免疫機能が低下し，炎症 は急速に拡大し遥延化する。本症例において, 患者は，当科入院時に感染が誘因となったケト アシドーシス状態にあると考兄られ，インスリ ンの投与と血糖, 電解質管理を必要とした。 
た糖尿病であったために創部の回復が遅く，治 療が遷延した。この原因としては糖尿病に対す る患者の病識が薄く, 厳重な禁止にもかかわら ず，間食をするなどの抵抗がみられたために血 糖值が安定せず，インスリンの投与值が決定で きず多大の時間を費した。このことを防止する ためには，患者家族を含めた糖尿病教育を早期 に実施する必要がある.

本疾患の処置としては気道確保が 重要であ る. 本症例に扮いては当科入院時に気道閉塞が あり，緊急気管切開術が施されたが，さらに炎 症が胸腔に拡がったため, 胸部外科による外科 的処置及び人工呼吸器による呼吸管理まで必要 とした，血液ガス等を参考にしながら，早期に 気道確保及び呼吸の管理が必要であると痛感さ せられた。

\section{結 語}

51才男性にみられた噶歯を感染源とし，炎症
が胸腔全体に波及し，腹腔にまで至った極めて 重篤なルードウィッヒ・アンギーナの 1 治験例 を報告した。

本症例の感染が重篤化ならびに遷延化に至っ た背景には糖尿病が合併して括り，糖尿病を有 する感染症疾患に対する諸注意にも言及した。

\section{参考文献}

1) 森 智昌, 他 : 口腔感染症における細菌学的検討 (4). 日本口腔科学会誌 $33: 46 \sim 54,1984$.

2 ) 渡辺元裕, 他: 最近 5 年間の口腔外科患者の細菌 検査成績について。 日本口腔科学会誌 $29: 216$ $\sim 2341980$.

3) Gross BD, et al: Ludwig's angina due to bacteroides. J Oral Surgery 34: 456 460, 1976.

$$
\left(\begin{array}{l}
\text { 別刷請求先 : 大越俊和 } \\
\text { 干2 } 213 \text { 川崎市宮前区营生 2-16-1 } \\
\text { 聖マリアンナ医科大学耳鼻咽喉科学教室 }
\end{array}\right)
$$

